\title{
Lactoferrin affects the adherence and invasion of Streptococcus dysgalactiae ssp. dysgalactiae in mammary epithelial cells
}

\author{
Fiona O’Halloran, ${ }^{* 1}$ Christine Beecher, ${ }^{*} †$ Valerie Chaurin, ${ }^{*}$ Torres Sweeney, $\ddagger$ and Linda Giblin* \\ *Teagasc Food Research Centre, Moorepark, Fermoy, Co. Cork, Ireland \\ †Department of Biochemistry, University College Cork, Cork, Ireland \\ $\ddagger$ School of Veterinary Medicine, University College Dublin, Belfield, Dublin 4, Ireland
}

\section{ABSTRACT}

Streptococcus dysgalactiae ssp. dysgalactiae is an important causative agent of bovine mastitis worldwide. Lactoferrin is an innate immune protein that is associated with many functions including immunomodulatory, antiproliferative, and antimicrobial properties. This study aimed to investigate the interactions between lactoferrin and a clinical bovine mastitis isolate, Strep. dysgalactiae ssp. dysgalactiae DPC5345. Initially a deliberate in vivo bovine intramammary challenge was performed with Strep. dysgalactiae DPC5345. Results demonstrated a significant difference in lactoferrin mRNA levels in milk cells between the control and infused quarters $7 \mathrm{~h}$ postinfusion. Milk lactoferrin levels in the Strep. dysgalactiae DPC5345 infused quarters were significantly increased compared with control quarters at $48 \mathrm{~h}$ postinfusion. In vitro studies demonstrated that lactoferrin had a bacteriostatic effect on the growth of Strep. dysgalactiae DPC5345 and significantly decreased the ability of the bacteria to internalize into HC-11 mammary epithelial cells. Confocal microscopy images of HC-11 cells exposed to Strep. dysgalactiae and lactoferrin further supported this effect by demonstrating reduced invasion of bacteria to HC-11 cells. The combined data suggest that a bovine immune response to Strep. dysgalactiae infection includes a significant increase in lactoferrin expression in vivo, and based on in vitro data, lactoferrin limits mammary cell invasion of this pathogen by binding to the bacteria and preventing its adherence.

Key words: lactoferrin, Streptococcus dysgalactiae ssp. dysgalactiae, mastitis

\section{INTRODUCTION}

Bovine mastitis infection has serious deleterious effects on milk quality and is a significant limiting factor

\footnotetext{
Received September 29, 2015.

Accepted February 14, 2016.

${ }^{1}$ Corresponding author: fiona.ohalloran@cit.ie
}

to profitable dairy farming worldwide (Kossaibati and Esslemon, 1997; Berry and Amber, 2005; Bar et al., 2008). Mastitis infection occurs when a bacterial pathogen gains entry to the mammary gland via the teat canal. Infection is then established through bacterial evasion of both the anatomical and humoral defense mechanisms of the mammary gland (Zhao and Lacasse, 2008).

Streptococcus dysgalactiae ssp. dysgalactiae has been described as both a contagious mastitis pathogen (Fox and Gay, 1993) and an environmental pathogen (Calvinho et al., 1998) and has been detected in clinical and subclinical bovine mastitis cases (Barrett et al., 2005; Piepers et al., 2007; Bitew et al., 2010; Girma et al., 2012). Traditional mastitis control programs have had limited effects on reducing the incidence of Strep. dysgalactiae infections due to the adaptability of the bacteria (Bolton et al., 2004). Streptococcus dysgalactiae have cell-associated and extracellular virulence factors that contribute to the establishment and persistence of IMI. In vitro studies have demonstrated that the bacteria can adhere to mammary epithelial cells and internalize (Almeida and Oliver, 1995; Calvinho and Oliver, 1998a). Once internalized within the cell, the bacteria can survive by evading the action of antimicrobial drugs and host immune defense components.

Conventional treatment for mastitis involves the administration of antibiotics. Antimicrobial resistance in mastitis pathogens is not yet considered a clinically relevant issue (Pyörälä, 2009; Oliver and Murinda, 2012); however, the intensive use of antibiotics can lead to the development of resistant strains (Hendriksen et al., 2008). In addition, dairy cows produce milk for human consumption; therefore, antibiotic traces in milk is a public health concern. The development of effective, alternative approaches to control or treat mastitis (or both) would be of significant benefit to the dairy industry. One approach would be to manipulate and enhance natural host defense mechanisms. However, different pathogens display distinct invasion and pathogenic mechanisms (Chaneton et al., 2008). Detailed knowledge of the specific host-pathogen interactions that are 
required to establish and develop IMI is fundamental to the design of adequate treatment and control policies.

Lactoferrin is an innate immune protein that is predominantly secreted in vivo by neutrophils and specific glandular tissue (Ling and Schryvers, 2006). Its production is both constitutively and differentially regulated in a tissue-specific manner (Teng, 2002). Lactoferrin is a multifunctional protein being associated with antibacterial, immunomodulatory, antiadhesive, and ironbinding properties (Chierici, 2001; Ueta et al., 2001; Ajello et al., 2002). It is described as broad spectrum, affecting the growth and proliferation of a variety of gram-negative and gram-positive pathogens (Adlerova et al., 2008) with both bacteriostatic and bacteriocidal effects (Kutila et al., 2003). Bovine milk lactoferrin levels change over the course of lactation, as well as in response to mammary gland infections (Kawai et al., 1999). Bahar et al. (2011) also demonstrated that genetic polymorphisms within the lactoferrin gene promoter can affect milk lactoferrin levels.

In general, streptococcal species are considered more resistant to the antibacterial effects of lactoferrin (Fang et al., 2000). This may be due to the fact that streptococcal species have low iron requirements (Weinberg, 1978) or it may be due to their ability to extract the metal from iron-containing host proteins (Ruiguang et al., 2009). Indeed lactoferrin binding proteins have been found in several streptococcal species, including Strep. uberis, Strep. agalactiae, and Strep. dysgalactiae (Park et al., 2002a), suggesting a role for lactoferrin in relation to streptococcal infections, which may have important implications for the pathogenesis of IMI. Patel et al. (2009) demonstrated that Strep. uberis isolates bind lactoferrin via a surface-exposed adhesion molecule, which they defined as the Strep. uberis adhesion molecule. These in vitro studies suggest that Strep. uberis hijacks lactoferrin to act as a bridging molecule between the bacterial cell surface and lactoferrin receptors on host mammary epithelial cells. This allows Strep. uberis to adhere, invade, and establish within bovine mammary epithelial cells. Interestingly, in vivo bovine studies by Chaneton et al. (2008) demonstrated that in subclinical cases of mastitis, bovine milk lactoferrin levels significantly increased in Strep. uberis infected quarters $(P<$ 0.001) when compared with uninfected quarters. It was hypothesized that Strep. uberis isolates were resistant to bovine lactoferrin activity and high levels of the lactoferrin in milk promoted the pathogenesis of Strep. uberis in vivo. Other mastitis-causing bacteria, including Staphylococcus aureus, Strep. dysgalactiae, and CNS, were not associated with a significant increase in bovine milk lactoferrin levels in these subclinical cases. These studies suggest that lactoferrin secretion in the bovine mammary gland is a pathogen-specific response.
Park et al. (2002b), using SDS-PAGE and Western blotting, confirmed the expression of 2 lactoferrin binding proteins in Strep. dysgalactiae isolates (52 and 74 $\mathrm{kDa})$ and 3 lactoferrin binding proteins in Strep. agalactiae isolates $(52,70$, and $110 \mathrm{kDa})$. However, studies on the specific interaction between these streptococcal species and lactoferrin is limited and thus the role of lactoferrin binding proteins in the pathogenesis of Strep. dysgalactiae and Strep. agalactiae intramammary infections must still be elucidated.

The aim of this study was to investigate the interaction in vitro between lactoferrin and Strep. dysgalactiae to identify whether this milk protein combats or promotes Strep. dysgalactiae infection. In vivo studies were conducted to quantify the changes in milk lactoferrin levels over the course of a mammary gland infection caused by a deliberate challenge with Strep. dysgalactiae.

\section{MATERIALS AND METHODS}

\section{Bacterial Culture}

Streptococcus dysgalactiae ssp. dysgalactiae DPC 5345 was isolated on a Teagasc farm from a clinical mastitis case. The isolate was confirmed as streptococcus by selective plating on blood-esculin agar plates and characterized to species level by 16S PCR (Riffon et al., 2001). A $2 \%$ inoculum of Strep. dysgalactiae DPC 5345 yielded $10^{8} \mathrm{cfu} / \mathrm{mL}$ when cultured overnight at $37^{\circ} \mathrm{C}$ in tryptic soy (TS) broth (Difco Laboratories, Detroit, MI).

\section{Animal Selection}

Five Holstein-Friesian cows were selected, based on their health status, for a deliberate intramammary challenge with Strep. dysgalactiae DPC 5345. These were spring-calving cows that were based on Teagasc research stations in the south of Ireland. Health status was determined using visual examination of milk and udders and milk SCC, with a count of $<200,000$ cells / $\mathrm{mL}$ considered as healthy. In addition, no pathogens were isolated from the quarter milks of test animals for 7 consecutive days before the challenge. Bacterial infusions and milk and blood sampling were performed under license from the Irish Department of Agriculture and Food and approved by the Teagasc ethical committee. Following infusions, the health of the animals was monitored by trained farm staff and veterinary personnel. For animal welfare purposes, intramammary-challenged cows received antibiotic treatment (Leo Yellow; Boehringer Ingelheim, Berkshire, UK) as soon as clinical signs of infection were observed. 


\section{Intramammary Challenge}

The intramammary challenge with Strep. dysgalactiae DPC5345 was performed according to a procedure described by Beecher et al. (2012). Briefly, overnight cultures of Strep. dysgalactiae DPC5345 were diluted with maximum recovery diluent (Oxoid Ireland, Dublin, Ireland) to prepare 2-mL suspensions at 2,500 cfu of dysgalactiae. This bacterial count was chosen as preliminary trials indicated that 2,500 $\mathrm{cfu}$ is sufficient to cause infection (Beecher et al., 2012). Immediately after morning milking, one quarter from each animal was infused with the bacterial suspension into the teat sinus via the streak canal. The contralateral quarter was infused with $2 \mathrm{~mL}$ of maximum recovery diluent only and served as the internal control. Total quarter milk samples (or up to $2 \mathrm{~L}$ volume) were collected from each infused and control quarter immediately before infusion and at $7 \mathrm{~h}, 24 \mathrm{~h}, 48 \mathrm{~h}, 7 \mathrm{~d}$, and $14 \mathrm{~d}$ postinfusion. From each milk sample $100 \mu \mathrm{L}$ was plated onto esculin blood agar plates (Thermo Scientific, Wilmington, DE) to monitor bacterial infection. Milk somatic cell counts were also determined using a Somacount 300 somatic cell counter (Bentley Instruments Inc., Chaska, MN). For animal welfare purposes, intramammary-challenged cows received antibiotic treatment (Leo Yellow, Boehringer Ingelheim, Berkshire, UK) as soon as clinical signs of infection were observed.

\section{RNA Extraction from Somatic Cells}

To isolate RNA from milk somatic cells, $1 \mathrm{~mL}$ of 0.5 $M$ EDTA (Sigma-Aldrich Ltd., Wicklow, Ireland) was added to each liter of milk and the samples were then centrifuged at $1,500 \times g$ for $30 \mathrm{~min}$ at $4^{\circ} \mathrm{C}$. The fat layer was removed and cell pellets were washed twice with PBS (pH 7.4) containing $0.5 \mathrm{~m} M$ EDTA. Pellets were then re-suspended in $1 \mathrm{~mL}$ of TriPure isolation reagent (Roche Diagnostics, East Sussex, UK) and RNA was extracted according to the manufacturer's instructions. All RNA was quality assessed through visualization on glyoxyl gels (1.5\%; Ambion, Applied Biosystems, Foster City, CA) and quantified using the Nanodrop 1000 (Thermo Scientific).

\section{Real-Time PCR}

One microgram of RNA was converted to cDNA using the QuantiTect Reverse Transcription Kit (Qiagen, Crawley, West Sussex, UK), and $1 \mu \mathrm{L}$ of cDNA was used per subsequent real-time PCR reaction. Primers designed by Li et al. (2009) were used to detect and amplify the lactoferrin gene (forward primer 5'-AAACAAGCATCGGGATTCCAG-3' and reverse primer
5'-ACAATGCAGTCTTCCGTGGTG-3'). Quantitative analysis was performed in a LightCycler 480 instrument (Roche Diagnostics) using a dilution series of external plasmid DNA standards $\left(10^{9}\right.$ to $10^{2}$ copies/ $\mu \mathrm{L}$; Pfaffl and Hageleit, 2001). Plasmid standards were created by cloning a cDNA PCR product into plasmid pCR TOPO (Invitrogen, Life Technologies, Carlsbad, CA). Cloning was confirmed by sequencing (Beckman Coulter Genomics, Essex, UK). One microliter of each dilution was used per $10 \mu \mathrm{L}$ of LightCycler reaction. The LightCycler 480 SYBR Green I Master kit (Roche Diagnostics) was used for quantification according to the manufacturer's instructions using $0.5 \mu M$ of each of the forward and reverse primers. The assay began with initial denaturation at $95^{\circ} \mathrm{C}$ for $10 \mathrm{~min}$, followed by 40 cycles of quantification with $5 \mathrm{~s}$ of denaturation at $95^{\circ} \mathrm{C}, 10 \mathrm{~s}$ of annealing at $60^{\circ} \mathrm{C}$, and $25 \mathrm{~s}$ of elongation at $72^{\circ} \mathrm{C}$. Melting curve analysis was performed by heating, from a temperature $5^{\circ} \mathrm{C}$ above the annealing temperature, to $95^{\circ} \mathrm{C}$ in the continuous fluorescence acquisition mode to ensure specificity of LightCycler product. LightCycler runs were performed in triplicate incorporating negative controls (no DNA template) in each run and according to MIQE guidelines (Bustin et al., 2009).

\section{Protein Quantitation by ELISA}

Milk lactoferrin was quantitated using an ELISA kit (Bethyl Laboratories Inc., Montgomery, TX) and according to the manufacturer's instructions. Milk samples were diluted 1:2,000, and standard curves were generated for each sample set. Minimum detection levels for lactoferrin were $7.8 \mathrm{ng} / \mathrm{mL}$, and lactoferrin concentrations were quantified by interpolating the absorbance values from the standard curve. Test samples were analyzed by ELISA in duplicate, and the analysis was performed on 2 separate occasions.

\section{Antibacterial Assay}

The antibacterial activity of a commercial bovine native lactoferrin protein (\#L9507, Sigma-Aldrich) was tested against Strep. dysgalactiae DPC5345. For this, an overnight culture of Strep. dysgalactiae DPC 5345 was diluted to $10^{7} \mathrm{cfu} / \mathrm{mL}$ in TS broth (Oxoid, Ireland) and $40 \mu \mathrm{L}$ of the culture was added to each test well in a 96 -well plate. The lactoferrin protein was initially prepared at a stock of $20 \mathrm{mg} / \mathrm{mL}$ by diluting in distilled water and sterile filtered using $0.45-\mu \mathrm{m}$ filters (Millipore, UK). The final concentrations of lactoferrin tested were $0.02,0.2,2.0,5.0$, and $10.0 \mathrm{mg} / \mathrm{mL}$. Plates were incubated at $37^{\circ} \mathrm{C}$ and growth curves were generated by measuring absorbance at $620 \mathrm{~nm}$ every hour for 
$24 \mathrm{~h}$ using a spectrophotometer. Assays were performed in triplicate.

\section{Cell Line and Tissue Culture}

The HC-11 murine mammary epithelial cell line used in this study was kindly donated by Wolfgang Doppler (Innsbruck Medical University, Innsbruck, Austria). Cells were grown and maintained in RPMI 1640 medium (Sigma-Aldrich) supplemented with $4 \mathrm{mM}$ L-glutamine (Sigma-Aldrich), 10\% fetal bovine serum (Sigma-Aldrich), $5 \mu \mathrm{g} / \mathrm{mL}$ insulin (Sigma-Aldrich), 10 $\mathrm{ng} / \mathrm{mL}$ epidermal growth factor (Sigma-Aldrich), 100 $\mathrm{U} / \mathrm{mL}$ penicillin (Sigma-Aldrich, Ireland), and $100 \mu \mathrm{g} /$ $\mathrm{mL}$ streptomycin (Sigma-Aldrich).

\section{Invasion Assays with Strep. dysgalactiae}

Invasion assays were performed on the same day, in triplicate, as per Calvinho and Oliver (1998b) with some minor modifications. Briefly, HC-11 cells were seeded into 24 -well plates at a density of $1 \times 10^{5}$ cells/ well and grown to confluency in antibiotic-free RPMI 1640 supplemented medium. An overnight culture of Strep. dysgalactiae DPC 5345 was washed 3 times in PBS (Sigma-Aldrich) and resuspended in antibioticfree RPMI 1640 supplemented medium, to a final concentration of $\sim 1 \times 10^{7} \mathrm{cfu} / \mathrm{mL}$. On the day of the assay, HC-11 cell monolayers were washed 3 times in PBS and 1 -mL aliquots of the bacterial culture $\left(1 \times 10^{7} \mathrm{cfu} / \mathrm{mL}\right)$ were added to each test well. Sterile-filtered solutions of lactoferrin, prepared with antibiotic-free RPMI 1640 supplemented medium, were added $(1 \mathrm{~mL})$ to test wells such that the final concentrations tested were $0.01,0.1$, 1.0 , and $2.0 \mathrm{mg} / \mathrm{mL}$ of lactoferrin. Control wells contained Strep. dysgalactiae DPC5345 culture and $1 \mathrm{~mL}$ of PBS only. Plates were incubated at $37^{\circ} \mathrm{C}, 5 \% \mathrm{CO}_{2}$ for $2 \mathrm{~h}$. Supernatants were aspirated off into sterile 1.5$\mathrm{mL}$ Eppendorf tubes and diluted 10-fold for bacterial counting. Culture wells were then washed 3 times with PBS $(1 \mathrm{~mL})$, followed by incubation for a further $2 \mathrm{~h}$ in RPMI 1640 supplemented medium containing $5 \mu \mathrm{g} /$ $\mathrm{mL}$ of penicillin and $100 \mathrm{U} / \mathrm{mL}$ of gentamicin. Following the second incubation, the medium was removed and cells were washed 3 times with $1 \mathrm{~mL}$ of PBS. The HC-11 cells were then lysed by adding $0.25 \%$ trypsin (Sigma-Aldrich) and $0.025 \%$ Triton X-100 (SigmaAldrich) and the lysates collected into sterile $1.5-\mathrm{mL}$ Eppendorf tubes and vigorously vortexed for $15 \mathrm{~s}$. Cell lysates were serially diluted 10 -fold $\left(10^{-1}\right.$ to $\left.10^{-4}\right)$ and 0.1-mL dilutions were plated onto TS agar plates for bacterial counting and incubated at $37^{\circ} \mathrm{C}$ overnight. Adherence, at lactoferrin concentrations tested, was expressed as $(\mathrm{cfu} / \mathrm{mL}$ in the cell lysates $) /(\mathrm{cfu} / \mathrm{mL}$ in the supernatant $) \times 10,000$ (Fang et al., 2000). Each lactoferrin concentration was tested in duplicate and the assays performed on 4 separate occasions.

\section{Confocal Scanning Microscopy and Live/Dead Staining}

For confocal microscopy experiments, HC-11 cells were seeded onto 10-cm-diameter tissue culture dishes (Sarstedt, Drinagh, Wexford, Ireland), at a concentration of $1 \times 10^{6}$ cells/well, and grown to confluency. A fresh overnight bacterial culture of Strep. dysgalactiae DPC5345 was washed 3 times with PBS and prepared in antibiotic-free RPMI 1640 supplemented medium to a final concentration of $\sim 1 \times 10^{7} \mathrm{cfu} / \mathrm{mL}$. A $2 \mathrm{mg} / \mathrm{mL}$ protein preparation of commercially available bovine Lactoferrin was prepared in PBS and labeled with a Dylight 633 Fluorescent dye using an Alexa Fluor 350 Protein labeling kit (Thermo Fisher Scientific, Dublin, Ireland), according to the manufacturer's instructions. One milliliter of the labeled protein solution was mixed with $1 \mathrm{~mL}$ of fresh bacterial culture $\left(\sim 10^{7} \mathrm{cfu} / \mathrm{mL}\right)$ and added to cell culture dishes containing confluent HC-11 monolayer of cells. Controls included HC-11 monolayers exposed to (a) $2 \mathrm{~mL}$ of antibiotic-free RPMI 1640 supplemented medium only and (b) $1 \mathrm{~mL}$ of antibioticfree RPMI 1640 supplemented medium mixed with 1 $\mathrm{mL}$ of bacterial culture $\left(\sim 10^{7} \mathrm{cfu} / \mathrm{mL}\right)$. All cell culture plates were incubated for $2 \mathrm{~h}$ at $37^{\circ} \mathrm{C}, 5 \% \mathrm{CO}_{2}$ and then the medium was removed before washing twice with PBS (5 mL).

Before imaging, cells were stained with the Live/Dead BacLight Bacterial Viability Kit solution (Molecular Probes Inc., Eugene, OR). An argon ion laser was used to generate the 488 line used for excitation. Imaging was performed using a Leica TCS SP5 confocal laser scanning microscope (Leica Microsystems, Heidelberg GmbH, Mannheim, Germany) using a $63 \times$ oil immersion objective $\left(A_{N}=1.4\right)$. RGB color images (24 bit), $512 \times 512$ pixels in size, were acquired. A minimum of $4 \mathrm{z}$-stacks were taken per sample with representative cross sections of micrographs shown.

\section{Statistical Analysis}

For statistical analysis, gene expression data were transformed by obtaining the natural logarithm. A hierarchical mixed model (PROC MIXED; SAS Version 9.1, SAS Institute Inc., Cary, NC) was used to quantify the effect of treatment (control or infused) on gene expression, and the dependent variable was transformed gene expression. Fixed effects included in the model were time relative to the start of the study, treatment, and time by treatment interaction. Where 
significant $(P<0.05)$, a covariate, which was the gene expression for the control and infused quarters at time zero, was included as a fixed effect. Time relative to the start of experiment was included as a repeated effect within the udder quarter, and cow was included as a random effect. Least squares means were extracted from the analysis, and differences between the control and infused quarters were considered significant at $P<$ 0.05 . With regard to the milk protein secretion data, statistical analysis was performed as above, without transformation, as data were normally distributed. As with gene expression data, differences between the control and infused quarters were considered significant at $P<0.05$.

For the antibacterial assay, a paired Student's $t$-test was used to investigate the effect of different lactoferrin concentrations on bacterial growth. The bacteriostatic effect of each concentration tested was considered significantly different from the control at $P<0.05$.

A paired Student's $t$-test was also used in the invasion assay to identify differences in bacterial counts recovered. The number of bacteria recovered from different experiments were considered significantly different at $P<0.05$.

\section{RESULTS}

The effect of a deliberate intramammary challenge with Strep. dysgalactiae on lactoferrin levels in vivo was investigated to determine if the bovine immune response to this mastitis pathogen included alterations to the transcription, secretion, or both of this antibacterial protein.

\section{Bacterial Growth in Infected Quarters Postintramammary Challenge}

Following the infusion of experimental quarters with 2,500 cfu Strep. dysgalactiae DPC5345, viable grampositive bacteria were recovered within $24 \mathrm{~h}$ from all quarters infused. Pulsed-field gel electrophoresis con- firmed Strep. dysgalactiae DPC5345 (data not shown). As soon as clinical signs of infection were observed (rectal temperatures $>38.5^{\circ} \mathrm{C}$, swollen udders, and SCC >200,000), animals received antibiotic (Leo Yellow) treatment. Four of the animals received antibiotic treatment $48 \mathrm{~h}$ postinfusion and one animal received antibiotics at $72 \mathrm{~h}$ postinfusion. Data postantibiotic treatment were discounted and not included in the analysis.

\section{In Vivo Levels of Lactoferrin mRNA and Protein Following Intramammary Challenge}

To investigate if lactoferrin gene expression lactoferrin protein levels, or both, in milk were affected by the deliberate Strep. dysgalactiae DPC5345 intramammary challenge lactoferrin mRNA and protein levels were measured in the control quarters and the infused quarters at $0,7,24$, and $48 \mathrm{~h}$ postinfusion. Control quarters acted as internal controls for each animal. A significant difference $(P<0.05)$ was found in lactoferrin mRNA levels between the control and infused quarters at 7 h postinfusion (Table 1) with lactoferrin mRNA levels reduced in the infused quarter. At all other time points tested, lactoferrin mRNA levels did not significantly differ between the control and infused quarters (Table 1). Lactoferrin protein levels were significantly increased $(P<0.05)$ in infused quarters compared with control quarters at $48 \mathrm{~h}$ postinfusion (Table 2 ).

\section{Antibacterial Activity}

To investigate the influence of a commercial preparation of bovine lactoferrin on the growth of the Strep. dysgalactiae culture DPC5345 in a laboratory setting, a 24-h growth curve was performed. The DPC5345 was cultured in complex medium with various concentrations of lactoferrin. Results from the 24-h growth curves demonstrated that lactoferrin had a bacteriostatic effect on Strep. dysgalactiae DPC5345 (Figure 1). At 14 $\mathrm{h} \geq 0.2 \mathrm{mg} / \mathrm{mL}$, lactoferrin had a significant effect on

Table 1. Lactoferrin transcript levels, per $50 \mathrm{ng}$ of total RNA, in milk from Streptococcus dysgalactiae-infused quarters compared with control quarters $^{1}$

\begin{tabular}{|c|c|c|c|c|c|}
\hline \multirow[b]{2}{*}{ Time } & \multicolumn{2}{|c|}{ Control quarter } & \multicolumn{2}{|c|}{ Strep. dysgalactiae-infused quarter } & \multirow[b]{2}{*}{$P$-value } \\
\hline & $\begin{array}{l}\text { Average lactoferrin } \\
\text { mRNA value }\end{array}$ & $95 \% \mathrm{CI}$ & $\begin{array}{l}\text { Average lactoferrin } \\
\text { mRNA value }\end{array}$ & $95 \% \mathrm{CI}$ & \\
\hline
\end{tabular}

${ }^{1}$ Values are given as the exponential of transformed data $\pm 95 \%$ CI. $P<0.05$ indicates a significance difference at that time point; $\mathrm{n}=$ number of animals measured at each time point. 


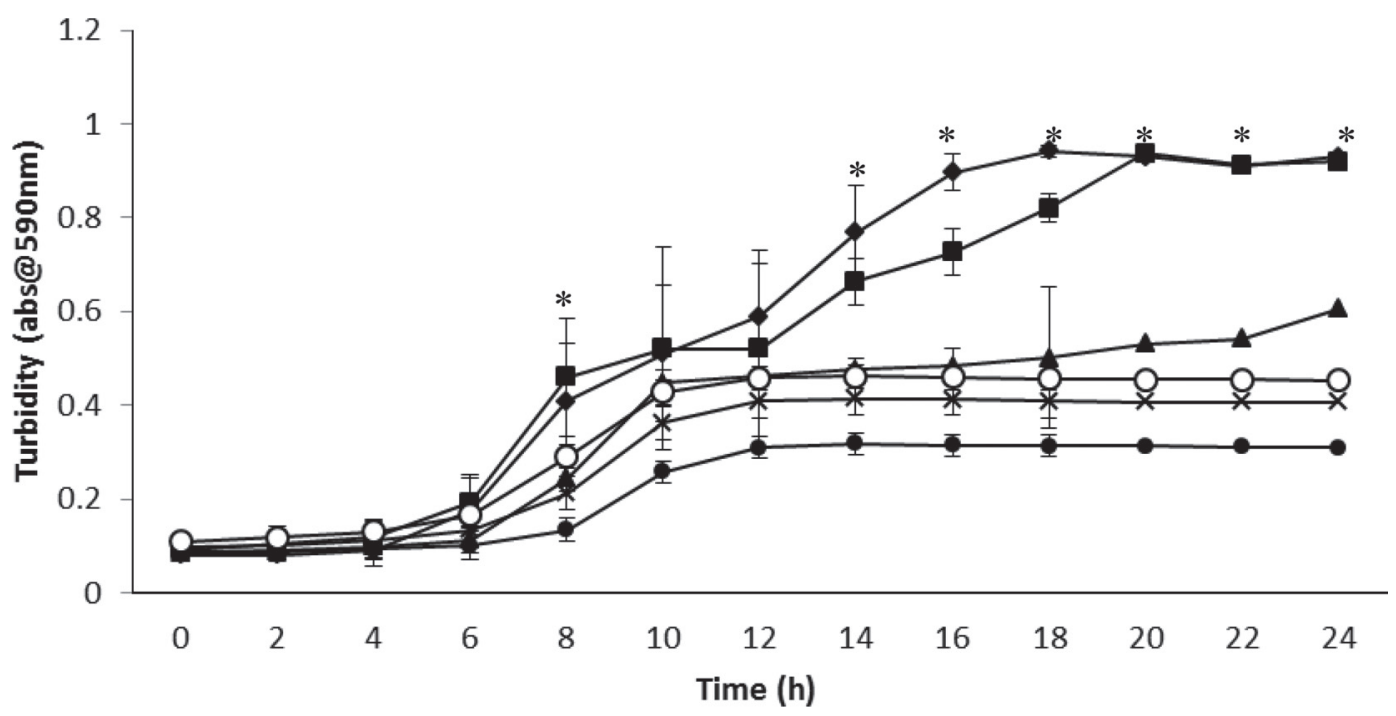

Figure 1. Twenty-four-hour growth curves of Streptococcus dysgalactiae in the presence of bovine lactoferrin. Streptococcus dysgalactiae

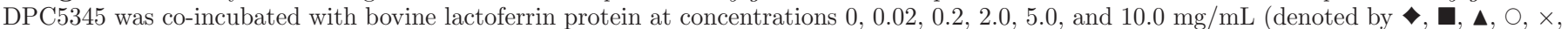
and $\bullet$, respectively). Growth of DPC5345 was measured by turbidity (absorbance at $590 \mathrm{~nm}$ ). Streptococcus dysgalactiae DPC5345 growth curves in the presence of each concentration of lactoferrin were compared with its growth in the absence of lactoferrin. From $8 \mathrm{~h}$ onward, a significant difference $(P<0.05)$, denoted as *, was present between growth of DPC5345 in the presence of $\geq 2 \mathrm{mg} / \mathrm{mL}$ lactoferrin compared with growth of DPC5345 alone. Error bars are standard deviation based on 3 replicate measurements.

bacterial growth $(P<0.05)$ when compared with the control (no lactoferrin).

\section{Invasion Assay and Confocal Imaging}

To examine if lactoferrin influenced the ability of Strep. dysgalactiae DPC5345 to invade epithelial cells, an invasion assay was performed using the $\mathrm{HC}-11 \mathrm{mu}-$ rine mammary epithelial cell line. HC-11 cell monolayers were incubated with $\sim 1 \times 10^{7} \mathrm{cfu} / \mathrm{mL}$ of fresh bacterial culture and a range of physiologically relevant concentrations of lactoferrin from 0.01 to $2.0 \mathrm{mg} / \mathrm{mL}$ (Schanbacher et al., 1993). After $4 \mathrm{~h}$ of incubation, lactoferrin reduced the number of live bacteria in the cell lysate in a dose-dependent manner with significant reductions associated with $0.1,1.0$, and $2.0 \mathrm{mg} / \mathrm{mL}$ of lactoferrin compared with the negative control. At 2 $\mathrm{mg} / \mathrm{mL}$ of lactoferrin, more than a log fold reduction in the number of internalized bacteria (4.1 $\log _{10} \mathrm{cfu} /$ $\mathrm{mL}$ ) was observed compared with the negative control $\left(5.52 \log _{10} \mathrm{cfu} / \mathrm{mL}\right)$ and $0.01 \mathrm{mg} / \mathrm{mL}$ of lactoferrin (5.34 $\log _{10} \mathrm{cfu} / \mathrm{mL}$; Table 3$)$. The adherence index value was calculated by dividing the number of bacterial colony-forming units in the cell lysate by the number of colony-forming units in the supernatant and therefore gives an indication of the ability of the bacteria to adhere and internalize into HC-11 cells. In the absence of lactoferrin, the adherence index value was 37.72. With each increasing lactoferrin concentration $(0.01,0.1,1.0$, and $2.0 \mathrm{mg} / \mathrm{mL}$ ), the adherence index value decreased $(32.5,20.67,13.54$, and 3.35 , respectively) in a dosedependent manner (Table 3), demonstrating decreased internalization. This effect was visually confirmed by confocal microscopy (Figure 2), which showed that in

Table 2. Lactoferrin protein $(\mu \mathrm{g} / \mathrm{mL})$ in milk from Streptococcus dysgalactiae- infused quarters compared with control quarters ${ }^{1}$

\begin{tabular}{|c|c|c|c|c|c|}
\hline \multirow[b]{2}{*}{ Time } & \multicolumn{2}{|c|}{ Control quarter } & \multicolumn{2}{|c|}{$\begin{array}{l}\text { Strep. dysgalactiae- } \\
\text { infused quarter }\end{array}$} & \multirow[b]{2}{*}{$P$-value } \\
\hline & Average value & SD & Average value & SD & \\
\hline $0 \mathrm{~h}(\mathrm{n}=5)$ & & & & & NS \\
\hline $7 \mathrm{~h}(\mathrm{n}=5)$ & 168 & 64 & 177 & 64 & NS \\
\hline $24 \mathrm{~h}(\mathrm{n}=5)$ & 215 & 64 & 259 & 64 & NS \\
\hline $48 \mathrm{~h}(\mathrm{n}=5)$ & 230 & 64 & 301 & 64 & $<0.05$ \\
\hline
\end{tabular}

${ }^{1}$ Values are given as the average data of 5 animals \pm SD. $P<0.05$ indicates significantly different at that time point; $\mathrm{n}=$ number of animals measured at each time point. 
Table 3. Effect of lactoferrin concentrations $(\mathrm{mg} / \mathrm{mL})$ on adherence and invasion of Streptococcus dysgalactiae DPC5345 $(\mathrm{cfu} / \mathrm{mL})$ into HC-11 mammary epithelial cells $\left(1 \times 10^{5} \text { cells } / \text { well }\right)^{1}$

\begin{tabular}{lccc}
\hline & & Invasion assay $^{2}$ & \\
\cline { 2 - 4 } $\begin{array}{l}\text { Lactoferrin } \\
(\mathrm{mg} / \mathrm{mL})\end{array}$ & $\begin{array}{c}\text { Live bacteria in } \\
\text { supernatant }(\mathrm{cfu} / \mathrm{mL})\end{array}$ & $\begin{array}{c}\text { Live bacteria in } \\
\text { cell lysate }(\mathrm{cfu} / \mathrm{mL})\end{array}$ & $\begin{array}{c}\text { Adherence } \\
\text { index }\end{array}$ \\
\hline 0 & $8.80 \mathrm{E}+07( \pm 8.68 \mathrm{E}+06)$ & $3.32 \mathrm{E}+05( \pm 4.93 \mathrm{E}+04)$ & 37.72 \\
0.01 & $6.80 \mathrm{E}+07^{\mathrm{a}}( \pm 5.68 \mathrm{E}+06)$ & $2.21 \mathrm{E}+05^{\mathrm{a}}( \pm 3.20 \mathrm{E}+04)$ & 32.5 \\
0.1 & $6.58 \mathrm{E}+07^{\mathrm{a}}( \pm 7.58 \mathrm{E}+06)$ & $1.36 \mathrm{E}+05^{\mathrm{b} *}( \pm 4.08 \mathrm{E}+04)$ & 20.67 \\
1.0 & $6.94 \mathrm{E}+07^{\mathrm{a}}( \pm 7.32 \mathrm{E}+06)$ & $9.40 \mathrm{E}+04^{\mathrm{b} * *}( \pm 3.45 \mathrm{E}+04)$ & 13.54 \\
2.0 & $3.70 \mathrm{E}+07^{\mathrm{b} * * *}( \pm 4.14 \mathrm{E}+06)$ & $1.24 \mathrm{E}+04^{\mathrm{b} * * *}( \pm 1.16 \mathrm{E}+03)$ & 3.35 \\
\hline
\end{tabular}

${ }^{\mathrm{a}, \mathrm{b}}$ Means within a column with different superscripts differ at the $P$-values indicated.

${ }^{1}$ Adherence index calculated as (cfu in the cell lysates)/(cfu in the supernatant) $\times 10,000$ (Fang et al., 2000).

${ }^{2}$ Values given represent mean of replicates $(n=8)( \pm$ SEM) of live bacterial recovered $(\mathrm{cfu} / \mathrm{mL})$ from HC-11 cell supernatant or cell lysate in the invasion assay.

${ }^{*} P<0.05 ;{ }^{* *} P<0.01 ;{ }^{* * *} P<0.005$.

the absence of lactoferrin viable Strep. dysgalactiae bacteria internalized into the mammary HC-11 cells (Figures 2A and 2B, respectively). When the Dylight 633 fluorescently labeled lactoferrin $(\sim 2 \mathrm{mg} / \mathrm{mL})$ was added to the HC-11 cells, the labeled protein bound to the bacteria at HC-11 cell membrane boundaries (Figure $2 \mathrm{C}$ ) and also to the bacteria that had internalized within the HC-11 cells (Figure 2D). These microscopic images indicate that Strep. dysgalactiae bacteria and the lactoferrin protein co-localize.

\section{DISCUSSION}

A deliberate bovine intramammary challenge with Strep. dysgalactiae resulted in a significant increase $(P<0.05)$ in milk lactoferrin protein compared with controls. Follow-up in vitro studies demonstrated that lactoferrin is a bacteriostatic agent that interferes with the ability of Strep. dysgalactiae to adhere and internalize into mammary epithelial cells. Co-localization images suggest a direct interaction between lactoferrin and Strep. dysgalactiae cells, demonstrating that this bacteria binds to the lactoferrin protein. The combined data indicate that a bovine immune response to Strep. dysgalactiae infection includes increased milk lactoferrin levels and this immune protein appears to limit mammary cell invasion of this pathogen by binding to the bacteria and reducing host cell adherence.

For some mastitis pathogens, it has been shown that lactoferrin promotes the pathogenicity of the bacteria. Patel et al. (2009) demonstrated, in vitro, that lactoferrin served as a molecular bridge for Streptococcus uberis species, promoting bacterial internalization into mammary epithelial cells and potentially providing an opportunity for this pathogen to survive against host defense mechanisms. In contrast to this our study indicates that lactoferrin plays a role in preventing infec- tion by Strep. dysgalactiae species by interfering with bacterial adhesion of the mammary epithelial cell. This has significance with regards to establishing intramammary infections by this pathogen, as adherence is an important stage in the pathogenesis of bovine mastitis (Calvinho et al., 1998).

The main bacteriostatic effect of lactoferrin is thought to be due to its iron-sequestering ability. When iron is depleted from the environment, it limits the growth of pathogens (Lacasse et al., 2008). However, streptococcal species have a low iron requirement (Fang et al., 2000) and therefore alternative mechanisms must exist by which lactoferrin is bacteriostatic against streptococci. Park et al. (2002a) demonstrated that, similar to Strep. uberis species, Strep. dysgalactiae express lactoferrin binding proteins. The existence of these proteins facilitates an interaction between lactoferrin and Strep. dysgalactiae cells (Park et al., 2002b) but the mechanism of the interaction and the physiological effect is unknown. Barboza et al. (2012) demonstrated that the glycan component of lactoferrin plays an essential role in pathogen recognition and inhibits bacterial binding to host epithelial cells. Other studies have confirmed that when lactoferrin binds with bacterial proteins it is capable of interfering with essential bacterial processes. Ochoa et al. (2003) and Gomez et al. (2003) have shown that lactoferrin can inhibit the function of type III secretory systems in the gram-negative pathogens enteropathogenic Escherichia coli and Shigella flexneri, respectively. These secretory systems play a significant role in the adherence and invasion of these gramnegative pathogens into mammalian cells. Lactoferrin was shown to inhibit pathogen adherence to host cells via a mechanism that involved proteolytic degradation of essential proteins required for bacterial contact and pore formation (Ochoa et al., 2003). Results from the current study demonstrate that lactoferrin is bacterio- 
static against Strep. dysgalactiae species, which could be due to the presence of these lactoferrin binding proteins. Further characterization of these proteins within Strep. dysgalactiae is required and would offer more insight into the mechanism of interaction between this streptococcal species and lactoferrin. This would help further elucidate the role that lactoferrin plays in limiting mastitis infection caused by Strep. dysgalactiae and could potentially lead to alternative control strategies for mastitis caused by this pathogen. Although it could be argued that only one strain was examined in the present study, Park et al. (2002b) demonstrated that there was no difference in the lactoferrin binding capacity of several Strep. dysgalactiae species investigated.

Lactoferrin mRNA levels were reduced in the early period of invasion of Strep. dysgalactiae. Lactoferrin protein levels did not differ within this period, but later, at $48 \mathrm{~h}$ postinfusion, a statistically significant increase $(P<0.05)$ was found in the average milk lactoferrin levels from the infused quarters compared with the control quarters. Bovine milk lactoferrin levels are reported in general to be between 20 to $200 \mathrm{mg} / \mathrm{L}$ (Rainard and Riollet, 2006), but levels vary from one animal to another, vary in mammary quarters, and as
(A)

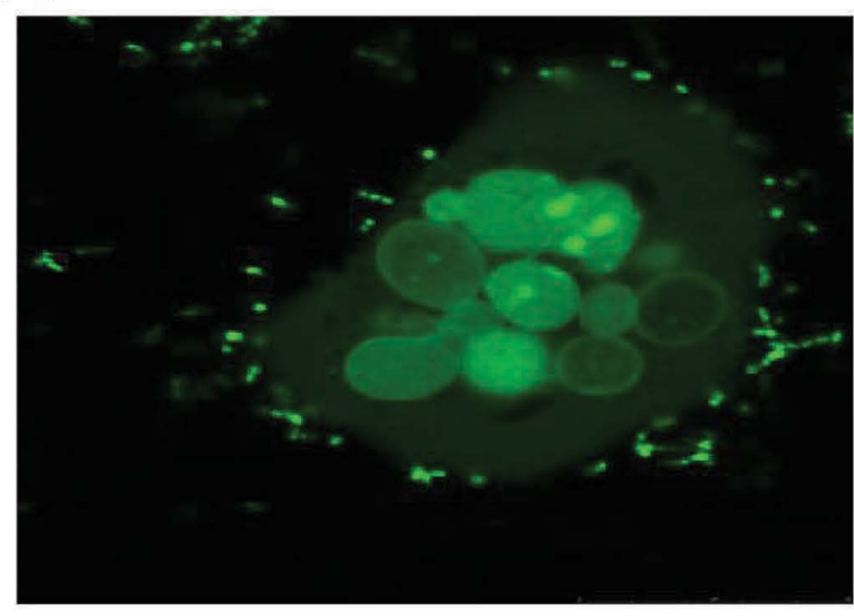

(C)

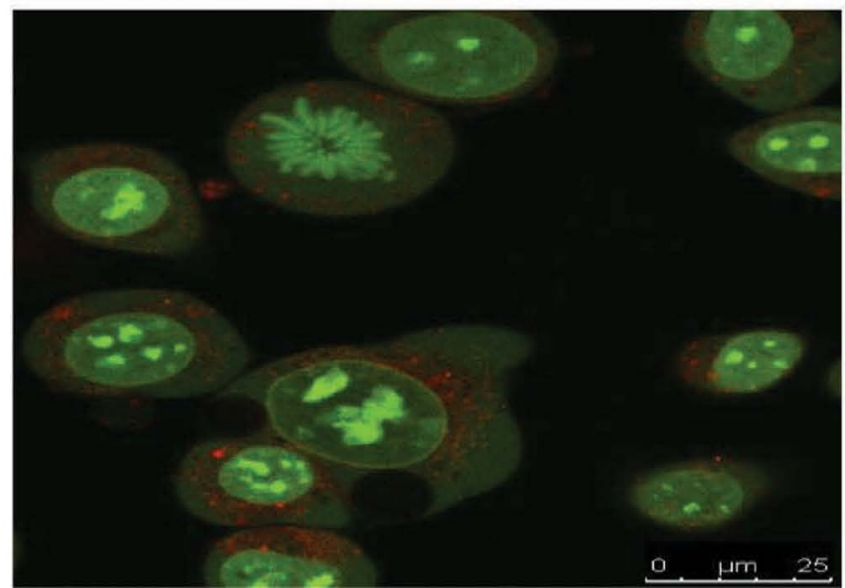

(B)

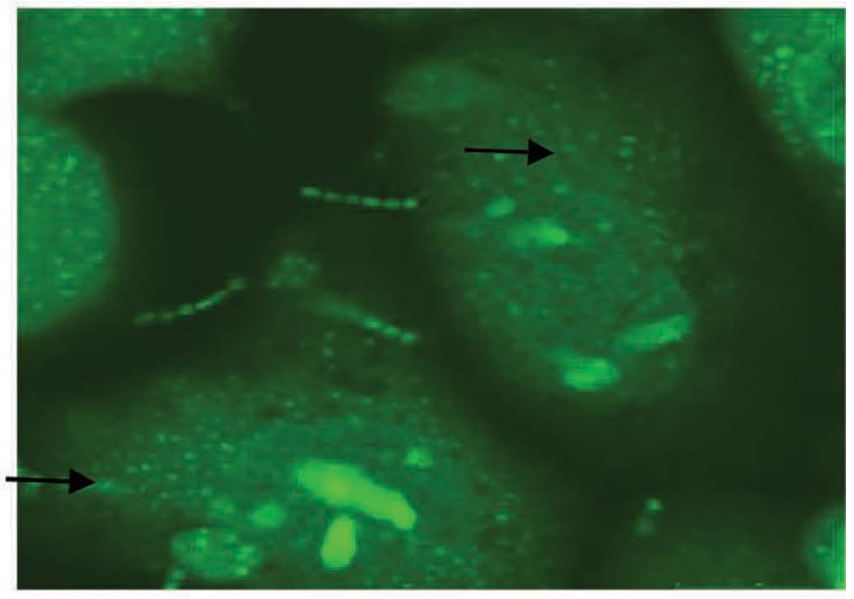

(D)

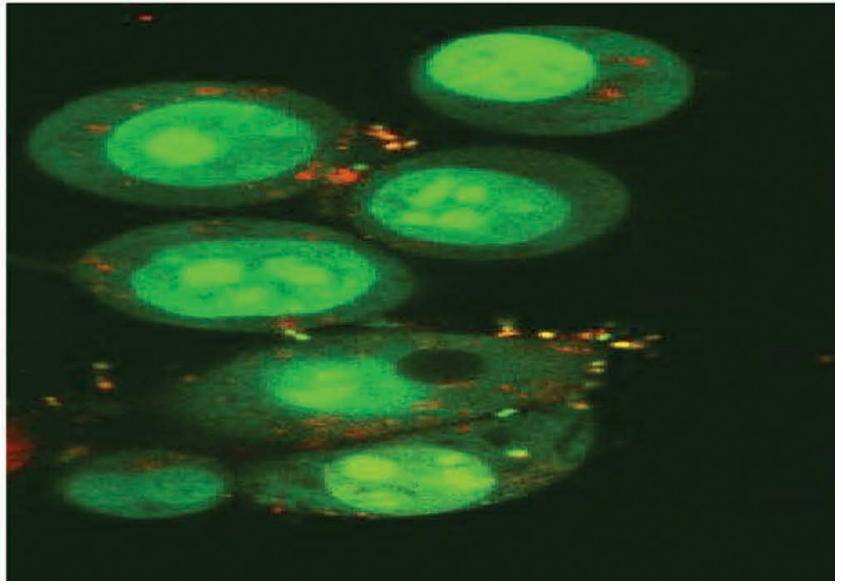

Figure 2. Confocal microscopic images of HC-11 mammary cells seeded at $1 \times 10^{6}$ cells and grown to confluency. The HC-11 cells were exposed to $1 \times 10^{7} \mathrm{cfu} / \mathrm{mL}$ Streptococcus dysgalactiae alone and with $2 \mathrm{mg} / \mathrm{mL}$ of Dylight 633 fluorescently labeled lactoferrin. All exposed cells were incubated for $2 \mathrm{~h}$ at $37^{\circ} \mathrm{C}, 5 \% \mathrm{CO}_{2}$, the medium was removed and the cells washed, then stained with Live/Dead Baclight viability stain to visualize cells. (A) Viable Strep. dysgalactiae (stained bright green) adhering to the viable HC-11 cell surface (scale 0-5 $\mu$ m), (B) following 2 $\mathrm{h}$ incubation, viable Strep. dysgalactiae (stained green) were seen internalized in viable HC-11 cells (identified with black arrows; scale 0-5 $\mu$ m), and (C) HC-11 cells (green stain) incubated with $2 \mathrm{mg} / \mathrm{mL}$ labeled lactoferrin (red stain) only. The lactoferrin crossed the cell membrane and

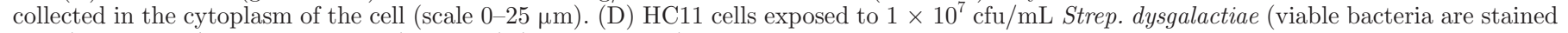
green) and $2 \mathrm{mg} / \mathrm{mL}$ of lactoferrin (red stain) (scale 0-20 $\mu \mathrm{m}$ ). 
lactation progresses the mean lactoferrin concentration increases (Cheng et al., 2008). In some cases of mastitis, levels also increase (Kawai et al., 1999). Chaneton et al. (2008) reported that in subclinical bovine mastitis cases, when the individual contribution of each pathogen was investigated, Strep. dysgalactiae infections were not associated with a significant increase in milk lactoferrin levels. In clinical mastitis cases with a significant increase in milk lactoferrin, the causative bacteria was not known. Whether the increase in milk lactoferrin levels observed in this study is biologically significant warrants further investigation. Mammary epithelial cells not only sense bacterial pathogens but also recruit neutrophils to the site of infection (Strandberg et al., 2005; Rainard and Riollet, 2006). This boosts the local concentration of lactoferrin protein as it is released from neutrophil secondary granules (Zhao and Lacasse, 2008). The increased levels of lactoferrin concentration at $48 \mathrm{~h}$ postinfusion may therefore be a result of neutrophil recruitment or delayed lactoferrin production from mammary epithelial cells or both.

The results from this study further emphasize that the interaction between the milk protein lactoferrin and bacteria is species specific. Further studies are required to characterize this interaction and understand the host-pathogen response in Strep. dysgalactiae infections to pave the way for the development of bacterial targeted mastitis therapies and prophylactics.

\section{ACKNOWLEDGMENTS}

The authors are grateful to Wolfgang Doppler, Innsbruck Medical University, for the kind donation of HC-11 cells. The authors also thank Mark Auty of the National Food Imaging Centre, Teagasc Moorepark, Co. Cork. This research was funded by the Food Institutional Research Measure (Department of Agriculture, Food and Fisheries, Ireland) Projects 06RDTMFRC437 and 06RDTMFRC445, the Irish Dairy Research Trust, and the Teagasc Retooling Program under the National Development Plan. Christine Beecher was in receipt of a Teagasc Walsh Fellowship.

\section{REFERENCES}

Adlerova, L., A. Bartoskova, and M. Faldyna. 2008. Lactoferrin: A review. Vet. Med. (Praha) 53:457-468.

Ajello, M., R. Greco, F. Giansanti, M. T. Massucci, G. Antonini, and P. Valenti. 2002. Anti-invasive activity of bovine lactoferrin towards group B streptococci. Biochem. Cell Biol. 80:119-124.

Almeida, R. A., and S. P. Oliver. 1995. Invasion of bovine mammary epithelial cells by Streptococcus dysgalactiae. J. Dairy Sci. 78:13101317.

Bahar, B., F. O'Halloran, M. J. Callanan, S. McParland, L. Giblin, and T. Sweeney. 2011. Bovine lactoferrin (LTF) gene promoter haplotypes have different basal transcriptional activities. Anim. Genet. 42:270-279.

Bar, D., L. W. Tauer, G. Bennett, R. N. González, J. A. Hertl, Y. H. Schukken, H. F. Schulte, F. L. Welcome, and Y. T. Gröhn. 2008. The cost of generic clinical mastitis in dairy cows as estimated by using dynamic programming. J. Dairy Sci. 91:2205-2214.

Barboza, M., J. Pinzon, S. Wickramasinghe, J. W. Froehlich, I. Moellert, J. T. Smilowitz, L. R. Ruhaak, J. Huang, B. Lonnerdal, J. B. German, J. F. Medrano, B. C. Weimer, and C. B. Lebrilla. 2012. Glycosylation of human milk lactoferrin exhibits dynamic changes during early lactation enhancing its role in pathogenic bacteriahost interactions. Mol. Cell Proteomics 11:M111.015248.

Barrett, D. J., A. M. Healy, F. C. Leonard, and M. L. Doherty. 2005. Prevalence of pathogens causing subclinical mastitis in 15 dairy herds in the Republic of Ireland. Ir. Vet. J. 58:333-337.

Beecher, C., M. Daly, R. P. Ross, J. Flynn, T. V. McCarthy, and L. Giblin. 2012. Characterization of the bovine innate immune response in milk somatic cells following intramammary infection with Streptococcus dysgalactiae subspecies dysgalactiae. J. Dairy Sci. 95:5720-5729.

Berry, D., and P. Amber. 2005. Derivation of a health sub-index for the economic breeding index in Ireland. Irish Cattle Breeding Federation Technical report. Pages 1-5. www.icbf.com/publications.

Bitew, M., A. Tafere, and T. Tolosa. 2010. Study on bovine mastitis in dairy farms of Bahir Dar and its environs. J. Anim. Vet. Adv. 9:2912-2917

Bolton, A., X. M. Song, P. Willson, M. C. Fontaine, A. P. Potter, and J. Perez-Casal. 2004. Use of the surface proteins GapC and Mig of Streptococcus dysgalactiae as potential protective antigens against bovine mastitis. Can. J. Microbiol. 50:423-432.

Bustin, S. A., V. Benes, J. A. Garson, J. Hellemans, J. Huggett, M. Kubista, R. Mueller, T. Nolan, M. W. Pfaffl, G. L. Shipley, J. Vandesompele, and C. T. Wittwer. 2009. The MIQE Guidelines: Minimum information for publication of quantitative Real-Time PCR experiments. Clin. Chem. 55:611-622.

Calvinho, L. F., R. A. Almeida, and S. P. Oliver. 1998. Potential virulence factors of Streptococci dysgalactiae associated with bovine mastitis. Vet. Microbiol. 61:93-110.

Calvinho, L. F., and S. P. Oliver. 1998a. Invasion and persistence of Streptococcus dysgalactiae within bovine mammary epithelial cells. J. Dairy Sci. 81:678-686.

Calvinho, L. F., and S. P. Oliver. 1998b. Characterization of mechanisms involved in uptake of Streptococcus dysgalactiae by bovine mammary epithelial cells. Vet. Microbiol. 63:261-274.

Chaneton, L., L. Tirante, J. Malto, J. Chaves, and L. E. Bussmann. 2008. Relationship between milk lactoferrin and etiological agent in the mastitic bovine mammary gland. J. Dairy Sci. 91:1865-1873.

Cheng, J. B., J. Q. Wang, D. P. Bu, G. L. Liu, C. G. Zhang, H. Y. Wei, L. Y. Zhou, and J. Z. Wang. 2008. Factors affecting the lactoferrin concentrations in bovine milk. J. Dairy Sci. 91:970-976.

Chierici, R. 2001. Antimicrobial action of lactoferrin. Adv. Nutr. Res. $10: 247-269$.

Fang, W., R. A. Almeida, and S. P. Oliver. 2000. Effects of lactoferrin and milk on adherence of Streptococci uberis to bovine mammary epithelial cells. Am. J. Vet. Res. 61:275-279.

Fox, L. K., and J. M. Gay. 1993. Contagious mastitis. Vet. Clin. North Am. Food Anim. Pract. 9:475-487.

Girma, S., A. Mammo, K. Bogele, T. Sori, F. Tadesse, and T. Jibat. 2012. Study on prevalance of bovine mastitis and its major causative agents in West Harerghe zone, Doba district, Ethiopia. J. Vet. Med. Anim. Health 4:116-123.

Gomez, H. F., T. J. Ochoa, L. G. Carlin, and T. G. Cleary. 2003. Human lactoferrin impairs virulence of Shigella flexneri. J. Infect. Dis. 187:87-95.

Hendriksen, R. S., D. J. Mevius, A. Schroeter, C. Teale, D. Meunier, P. Butaye, A. Franco, A. Utinane, A. Amado, M. Moreno, C. Greko, K. Stärk, C. Berghold, A. L. Myllyniemi, D. Wasyl, M. Sunde, and F. M. Aarestrup. 2008. Prevalence of antimicrobial resistance among bacterial pathogens isolated from cattle in different European countries: 2002-2004. Acta Vet. Scand. 50:28. www.actavetscand.com/content/50/1/28. 
Kawai, K., S. Hagiwara, A. Anri, and H. Nagahata. 1999. Lactoferrin concentration in milk bovine clinical mastitis. Vet. Res. Commun. 23:391-398.

Kossaibati, M., and R. Esslemon. 1997. The cost of production diseases in dairy herds in England. Vet. J. 154:41-51.

Kutila, T., S. Pyorala, H. Saloniemi, and L. Kaartinen. 2003. Antibacterial effect of bovine lactoferrin against udder pathogens. Acta Vet. Scand. 44:35-42.

Lacasse, P., K. Lauzon, M. S. Diarra, and D. Petitclerc. 2008. Utilization of lactoferrin to fight antibiotic-resistant mammary gland pathogens. J. Anim. Sci. 86(Suppl.):66-71.

Li, Y., G. V. Limmon, F. Imani, and C. Teng. 2009. Induction of lactoferrin gene expression by innate immune stimuli in mouse mammary epithelial HC-11 cell. Biochimie 91:58-67.

Ling, J. M. L., and A. B. Schryvers. 2006. Perspectives on interactions between lactoferrin and bacteria. Biochem. Cell Biol. 84:275-281.

Ochoa, T. J., M. Noguera-Obenza, F. Ebel, C. A. Guzman, H. F. Gomez, and T. G. Cleary. 2003. Lactoferrin impairs type III secretory system function in enteropathogenic Escherichia coli. Infect. Immun. 71:5149-5155.

Oliver, S. P., and S. E. Murinda. 2012. Antimicrobial resistance of mastitis pathogens. Vet. Clin. North Am. Food Anim. Pract. $28: 165-185$.

Park, H.-M., R. A. Almeida, D. A. Luther, and S. P. Oliver. 2002b. Binding of bovine lactoferrin to Streptococcus dysgalactiae ssp. dysgalactiae isolated from cows with mastitis. FEMS Microbiol. Lett. 208:35-39

Park, H.-M., R. A. Almeida, and S. P. Oliver. 2002a. Identification of lactoferrin-binding proteins in Streptococcus dysgalactiae ssp. dysgalactiae and Streptococcus agalactiae isolated from cows with mastitis. FEMS Microbiol. Lett. 207:87-90.

Patel, D., R. A. Almeida, J. R. Dunlap, and S. P. Oliver. 2009. Bovine lactoferrin serves as a molecular bridge for internalisation of Streptococcus uberis into bovine mammary epithelial cells. Vet. Microbiol. 137:297-301.
Pfaffl, M. W., and M. Hageleit. 2001. Validities of mRNA quantification using recombinant RNA and recombinant DNA external calibration curves in real-time RT-PCR. Biotechnol. Lett. 23:275-282.

Piepers, S., L. De Meulemeester, A. de Kruif, G. Opsomer, H. W. Barkema, and S. De Vliegher. 2007. Prevalence and distribution of mastitis pathogens in subclinically infected dairy cows in Flanders, Belgium. J. Dairy Res. 74:478-483.

Pyörälä, S. 2009. Treatment of mastitis during lactation. Ir. Vet. J. 62(Suppl. 4):S40-S44.

Rainard, P., and C. Riollet. 2006. Innate immunity of the bovine mammary gland. Vet. Res. 37:369-400.

Riffon, R., K. Sayasith, H. Khalil, P. Dubreuil, M. Drolet, and J. Lagacé. 2001. Development of a rapid and sensitive test for identification of major pathogens in bovine mastitis by PCR. J. Clin. Microbiol. 39:2584-2589.

Ruiguang, G., S. Xuesong, and H. Qingyu. 2009. Iron acquisition by Streptococcus species: An updated review. Front. Biol. China 4:392-401.

Schanbacher, F. L., R. E. Goodman, and R. S. Talhouk. 1993. Bovine mammary lactoferrin: implications from messenger ribonucleic acid (mRNA) sequence and regulation contrary to other milk proteins. J. Dairy Sci. 76:3812-3831.

Strandberg, Y., C. Gray, T. Vuocolo, L. Donaldson, M. Broadway, and R. Tellam. 2005. Lipopolysaccharide and lipoteichoic acid induce different innate immune responses in bovine mammary epithelial cells. Cytokine 31:72-86.

Teng, C. T. 2002. Lactoferrin gene expression and regulation: An overview. Biochem. Cell Biol. 80:7-16.

Ueta, E., T. Tanida, and T. Osaki. 2001. A novel lactoferrin peptide FKCRRWQWRM, suppresses Candida cell growth and activated neutrophils. J. Pept. Res. 57:240-249.

Weinberg, E. D. 1978. Iron and infection. Microbiol. Rev. 42:45-66.

Zhao, X., and P. Lacasse. 2008. Mammary tissue damage during bovine mastitis: Causes and control. J. Anim. Sci. 86(Suppl.):57-65. 